\title{
中高年者における前十字靫帯再建術後の成績
}

\begin{tabular}{|c|c|c|c|c|c|}
\hline 黒 & 木 & 理 & 秀・緒 & 方 & 公 \\
\hline 原 & & 道 & 也・松 & 浦 & 一 \\
\hline 藤 & 原 & & 明・星 & 子 & 一 \\
\hline 山 & 田 & & 嗣 - 金 & 宮 & \\
\hline 佐 & 伯 & 和 & 彦・城 & 島 & \\
\hline
\end{tabular}

\section{Post Operative Assessment of Anterior Cruciate Ligament Reconstruction in Older Patients}

by

\author{
Yoshihide Kuroki, Kosuke Ogata, Michiya Hara, Ippei Matsuura, \\ Akira Fujiwara, Ichiro Hoshiko, Masatoshi Yamada, \\ Tsuyoshi Kanamiya, Kazuhiko Saeki and Hiroshi Joujima \\ Department of Orthopaedic Surgery, School of Medicine, \\ Fukuoka University, Fukuoka, Japan
}

Anterior cruciate ligament ( $\mathrm{ACL}$ ) reconstruction in older patients will occur more often as patients live longer and play sports more.

We investigated 13 patients with the Lysholm score, aged over 40 -years-old after ACL reconstraction. The patients were seven male and six female, with an average age of 47-years.

The mean Lysholm score was 92.8 points. Preoperatively twelve of thirteen patient played sports and postoperatively nine of twelve patients (75\%) continued playing.

As ACL reconstruction for young patients is valuable, the operation for older patients is also of value.

Key words : anterior cruciate ligament reconstruction（前十字勒帯再建術), older patients (中高年 患者), Lysholm score (Lysholm スコア)

はじめに

前十字勒帯再建は若年者に対して施行することが多 いが，最近はレクレーションレベルでのスポーッや仕 事を続けるために中高年者でも施行されることが多く なった．今回我々は当科で行った 40 才以上の $\mathrm{ACL}$ 再建術の術後成績につき評価を行ったので報告する。

\section{対象亡方 法}

対象は 1992 年 1 月より 96 年 10 月の間に当科及び
関連の施設で施行した 40 歳以上の ACL 再建症例 14 例のうち追跡調查し得た 13 例（男性 7 例, 女性 6 例） である. 手術時平均年齢 47.1 歳（40 歳～65 歳)， 40 歳台 10 例, 50 歳台 2 例, 60 歳台 1 例であった.

平均 follow up 期間は 3.0 年 ( 8 ケ月〜 5 年 5 ケ月), 評価は Lysholm score を用いて行った。

結果

術後の total 及び項目別の lysholm score の結果の 平均を示す (表 1 ). 総合点は 71 点〜100 点の間であ 
り平均 92.8 点であった。 また術前 13 例中 12 例まで がスポーツ愛好者であり術後の復帰レベルは不可の症 例は存在しなかった（表 2 ).

\section{症}

例

代表症例を呈示する。

65 歳, 男性. 45 年前ラグビーにて受傷. 外科的加 療は受けていなかったが，50 歳時よりゴルフを始め た。 ハンディキャップ 4 であり，県の代表選手である。 プレー中の givingway, 痛みが強くなり手術を希望 した。初診時左膝の腫脹, Lachmann test, Pivot shift 陽性で，ストレス撮影側面像の健側比では前方
引出し $2 \mathrm{~mm}$ であった。術前の MRI では ACL は不 明瞭で lateral meniscus は損傷が疑われた（困 1 ）。 術中所見では ACL は既に瘢痕化しており，ACLの 再建術を施行した（図 2 ). ままた術前 McMurray test が陽性であり, lateral meniscusには中節から後節 にかけての変性と縦断裂を認め, trimming を加えて いる. 術後 9 ケ月の抜釘時の鏡視所見では ACL は volume, tension とも良好で lateral compartment にO. A. changeの進行は認められなかった（図 3 ). 当症例の術前及び手術後 2 年の時点での Lysholm score での変化は, total score で 43 点から 90 点に 大きく上昇している（表 3 )。この患者はゴルフ愛好

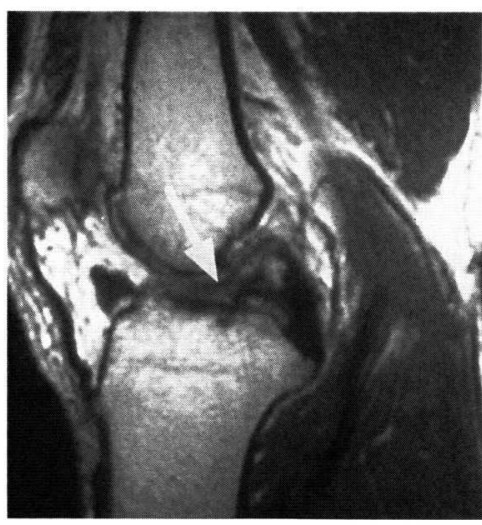

a

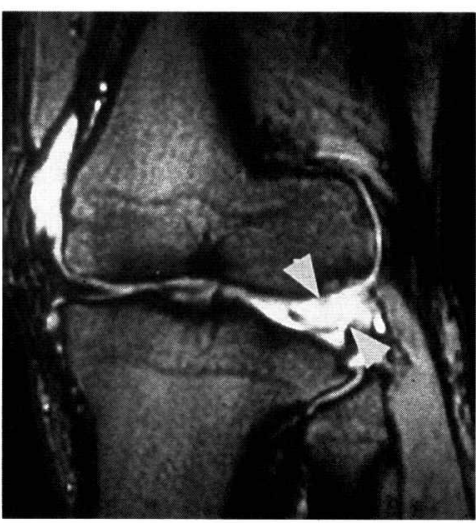

b

図 1 「術前 MRI」

a. ACL に一致する低信号域が認められない.

b. lateral meniscus は mixed intersily であり, 損傷を疑わせた.

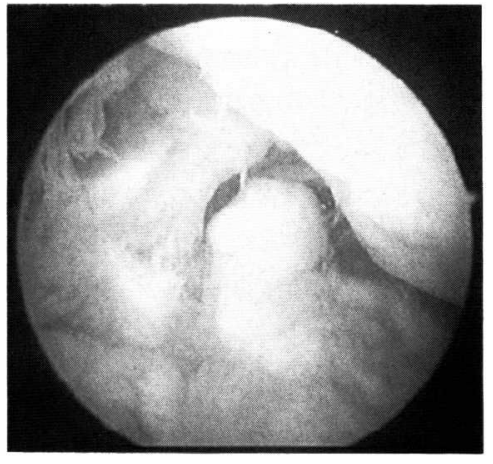

a

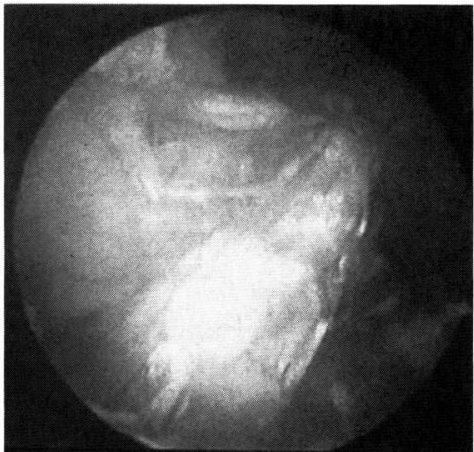

$\mathrm{b}$

図 2 「術中鏡視所見」

a 、洀痕化 $\mathrm{ACL}$

b. 再建後 ACL 


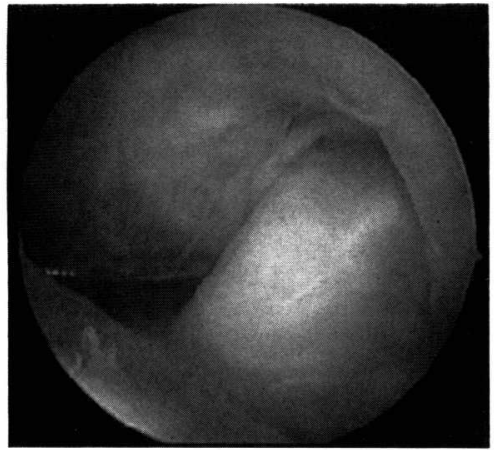

a

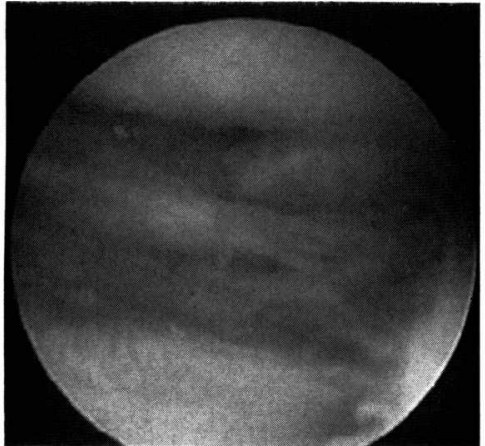

b

図 3 「術後 9 ケ月の鏡視所見」

a. ACL は volume, tension 共に良好であった.

b. lateral compartmentに O. A. の進行は認めなかった.

者であり, limping, support, locking と言った項 目は術前より full score であり ADL 上は大きな問題 となっていなかったが，ゴルフのラウンド時に長距離 を歩くのに痛み, 腫脹等で困難を感じ, また instability あプレーの障害となっていたため手術を希望した. 術後これらの点が改善し 67 歳の現在もプレーを続け ている.

\section{考察}

近年のスポーツ人口の増加に伴って 40 歳以上の中 高年者の ACL 損傷む増加しつつある。従来あまり手 術適応がないとされていたこれらの年齢層の患者でも レクレーションレベルでのスポーツ復帰を希望するも のも多く, instability がその妨げとなっていること が多い1). 手術適応については, 保存的加療を行った 後, それでも患者の満足度が低く, 更にそれ以上のこ とを望むばあい手術を検討する，今回の症例でもほ之 んぞが日常生活には問題の無い人々であったが, 術前 よりスポーツをしなかった1名を除いた 12 名のうち 9 名が術後も継続してスポーツを行っており，こうし た意欲の高い人々は術後のリハビリテーションに対し ても意欲的であり, 従ってスポーツ復帰度も, 術後の 満足度も高く，どの年澮層であっても手術適応になり 得ると思われた2).

術後のリハビリテーションに関しての問題点として 若年者と比較した場合筋力の低下は否め無いが，当科 では術後早期のリハビリを行うことによりこの問題を
克服している. また中高年者における別の問題として, 若年者と比較すると半月損傷や軟骨損傷により痛みを 呈する症例が多いと思われるが，今回の術後評価で最 低点であった症例は術後一旦かなりの改善を見ていた が, 術後 3 年 4 ケ月経過した調查の時点で instability の項目ではfull score であったにあ関わらず，平 地歩行時や階段での痛みがあり, 変形性関節症の進行 のためと思われた。 そのため今回の症例では群を抜い て低得点であった，我々は鏡視を行った際，進行した 変形性関節症であり，また患者の主訴が instability でなく痛みである場合，そ扎らの症例には慎重に対応 すべきであり, 再建術の適応とはなりにくいと考えて いる.

\section{ま と め}

1. 当科における 40 歳以上の中高年者 ACL の術 後成績は若年者と比較しても見劣りするものではなく, 意欲のある患者では術後の満足度も高い。

2.今後は高齢化により中高年者であってもレクレー ションレベルのスポーツをする機会は増加すると思わ れ今後 ACL 再建の適応は拡大すると思われる.

\section{参 考 文 献}

1）一戸貞文ら：40 歳以上の ACL 損傷に対する再建術の 適応，日整会誌，70(2)(3)：S565，1996.

2) Alan Barber F. et al. : Is an cruciate ligament reconstruction outcome age dependent? Arthroscopy, 12 (6) : 720-725, 1996 